\title{
Hypothetical Model of Guidance and Counseling Career Program Based Social Class of Vocational High School Information and Communication Technology in Tangerang
}

\author{
Dede Rahmat Hidayat $^{\text {a }}$, Rika Kartikawati ${ }^{\text {b }}$, Susi Fitric \\ Program Of Magister Guidance And Counseling \\ Universitas Negeri Jakarta \\ Corresponding e-mail: ${ }^{a}$ d_r_hidayat@yahoo.com, ${ }^{b}$ rikasacapermata@gmail.com, ${ }^{c}$ susi.fitri.kuliah@gmail.com)
}

\begin{abstract}
Abstrack
The research is aimed to develop and examine the feasibility of Hypothetical Model of Guidance And Counseling Career Program Based Social Class of Vocational High School Information and Communication Technology At Tangerang. The program is developed to increase the capacity perceived by the students in choosing an occupation despite constrains. The research instrument used to measure students' performance appraisal is work volition scale-student version. The research method uses Research and Development $(\mathrm{RnD})$. The research step is limited up to eight steps, consists of planning and doing learning formative evaluation. The research result of guidance and counseling carrier area program based social class of vocational high school information and technology at Tangerang has examined by guidance and counseling experts with total score 30 or in the category of good. The research conclusion of guidance and counseling carrier area program is feasible to be used. It can be seen from the components mostly in the category of good. It indicates that guidance and counseling carrier area program has feasibility in component program which aimed in making the program to be reached.
\end{abstract}

Keywords : Guidance and Counseling Career Program for SMK, social class, Work Volition scale

\section{INTRODUCTION}

Vocational High School to produce graduates who are ready to work, but on topics that are open from SMK graduates are still more than the open salary that comes from high school graduates. Referring data from the central statistical body showing open conditions from the vocational education level as of August 2014 as much as $11.24 \%$ while open unemployment from high school education at the same time as much as $9.55 \%$ (www.bps.go.id). This shows the presence of togetherness with vocational education, not necessarily making a person able to easily tread his career. Since industrialization is becoming more widespread, the number and diversity of work choices grow geometrically (Herr, Cramer, \& Niles, 2004; Savickas \& Baker, 2005).

At the same time, the choice of education is increasing, leading to a sense among adolescents and adults about determining their optimal vocational / work direction (Keller \& Viteles, 1937). An increasingly diverse career choices do not necessarily make any individual can easily choose the desired career. Ideally, when individuals make career choices, they will tailor it to their personal preferences and what is needed in the work environment, leading to maximum performance and satisfaction. However, individuals with a limited range of career choices generally have jobs that do not fit their personal preferences (Blustein et al., 2002). The selection process of the career itself is a simple process, the individual might consider some support and obstacles before finally deciding (or being forced to decide) to choose a particular job.

Individuals from lower social classes, for example, tend to have limited job options due to the constraints they have. In addition, support from families and the environment was more minimal obtained by children who come from lower social class. Children living in poverty lack their cognitive stimulating environments, with poor print media availability, fewer age-appropriate toys, fewer educational materials in digital form, and more exposure to television media (Bradley \& Corwyn, 2002 ; Duncan \& Brooks-Gunn, 1997; Evans 2004). Children living in poverty lack social support, and their parents are less responsible and more authoritarian (Evans, 2004).

According to Thompson \& Hickey (2008), social class (social economic status) is defined in the context of individual income, employment, education and prestige in society. So the social economic status (social class) is often measured by the combination of individual income with the length of one's education (the high level of one's education). Meanwhile, Tischler (2011) defines a social class consisting of categories of people sharing similar opportunities, similar economic and job positions, similar lifestyles, and similar attitudes and behaviors. One indicator of social class is income. According to the world bank (world bank), a person is said to be poor if the income per day is $\$ 2$, or equivalent to $\mathrm{Rp}$. 720,000 if the rupiah exchange rate against $\$$ is $\mathrm{Rp}$. 
13,000. The statistical center determines the standard of poverty line of Tangerang city of Rp. 421. 554, smaller than that determined by the world bank. Meanwhile, according to The Boston Consulting Group, based on monthly household expenditure, the category of the poor in Indonesia is those whose monthly expenditure is below the RP. $1,000,000$. Based on the above categories, then in this study, the lower classes in the students whose parents do not work and or have a maximum income of $\mathrm{Rp}$. $1,000,000$. This is in line with several studies conducted at Vocational Schools related to social and career classes, that social classes have an influence on some career variables. Mulyono (2014) stated that the socio-economic status has an effect on the career aspiration of SMK students in Kebumen Regency by 2\%. Another study conducted by Kawakib (2008) shows that the socioeconomic status of parents together with intelligence and self-efficacy accounted for $40.2 \%$ of career decision making students. Not much different from the results of research conducted by Mansur (2005) which states that there is an effective contribution of $32.50 \%$ collectively between the socioeconomic status of parents and selfconcept of student career decision making.

Seeing that the status of individual social classes impacts on the perceived capacity to choose a job, the researcher sees the need to create a design of a career-based career counseling program. This counseling guidance plan is expected to help lower class students understand the obstacles they face and the classroom they are experiencing so that students can better understand themselves and can make career decisions that are suitable for him. It is considered important not only to determine the assistance in the form of aspects (Such as providing scholarships for example) but also to facilitate BK teachers and schools in providing assistance in other forms in various aspects (psychological aspects, learning and so on).

\section{THEORETICAL FRAMEWORK}

1. Psychology of work (work psychology) and work volition (willingness to work)

The issue of work is still a concern for psychologists working, they almost often do research with the work related that is as done by counseling psychologists who have produced a very rich literature on certain aspects of vocational behavior such as career expansion, career planning, and retrieval Career decisions (Brown \& Lent 2005, Walsh \& Savickas, 2005).

Psychology of work (PWF) (Blustein, 2008) was developed to speak with the life of everybody's work, not just people from special backgrounds or with various choices Blustein (2008) notes that for all individuals work can be a mechanism to meet the needs of life, Linkage, and self-determination, which in turn can lead to greater meaning of life and satisfaction (Blustein 2006, Ryan and Deci, 2000 and Schultheiss, 2003)

Work volition is constructed by three main constructs, namely volition, financial constraints, and structural constraints. Volition refers to the perceived capacity of individuals to make employment choices, while financial constraints refer to financial constraints that are felt to achieve volition, such as limited finances, or the need to support the family. While structural constraints are structural constraints faced in achieving volition, such as a lack of work of interest in one particular area or other external factors.

The Work Volition Scale (WVS) scale in its development has adjusted the model for students in the school, resulting in the Work Volition ScaleStudent Version. The student's version of volition has two main constructs, namely general volition, and volitional constraints. General volition contains 7 items of statements that measure the perceived capacity of an individual to make a choice of work, while volitional constraints contain 9 items of statements that measure the constraints of achieving volition.

In a study conducted by Duffy, Diemer, \& Jadidian (2011), students' versatility of work has a strong correlation with the general self-perception and is correlated with one's belief in career decisions (CdSe).

\section{BK career program in SMK}

In Permendikbud no 111 (2014) mentioned that guidance and counseling is systematic, objective, logical and sustainable and programmed by counselors or guidance and counseling teachers to facilitate the development of students / counselee to achieve independence in his life. According to Gysbers and Henderson (2006) guidance and counseling is a program. The guidance and counseling program has the same characteristics as the educational program in which the learners stand, the activities and the process of assisting the students in achieving standard, professional certified members, materials and research results, programs, members and evaluation results.

Referring to the guidance counseling component component proposed by Gysbers and Henderson (2006), there are four main components in counseling and guidance programs: 1) Guidance Curriculum, 2) Responsive Service, 3) individual planning, 4) support system.

\section{Social class in BK}

Guidance Career counseling is intended to help students make career decisions. Related to that, career counseling counseling needs to see the process of making career decisions through various perspectives, one of them through sociological and economic approach. 
According Osipow (1983) sociological approach is fundamentally based on the idea that elements outside the individual have a strong influence on the individual throughout his life, including education and employment decisions. The degree of individual freedom in the choice of occupation or position far from what was originally assumed, and one's selfesteem is not free from the expectations of society. Instead, society presents job opportunities / positions in a pattern relating to social class membership. With regard to social class and career development, Lipsett (in Osipow, 1983) states that social class membership affects certain career choices when he reaches adolescence.

Perry \& Wallace (2013) states that sociologists have helped understand the realm of why individuals born in certain circles or families tend to react similarly to educational inequalities and experience the same pattern of segregation of work that has been experienced by previous generations in their families. This makrolevel's explanation views social class as a significant determinant in one's career path.

Social class and class structure are the forces that affect humans in most of the things that are done in life. Human behavior varies greatly according to the class it possesses and how one's class position and class consciousness is translated into action. Meanwhile, according to Tischler (2011) social class is defined as: A social class consisting of similar categories of similar economic and vocational positions, similar lifestyles and similar attitudes and behaviors.

The social class consists of people with one particular category who share equal opportunities, equal economic and vocational positions, same lifestyle, and similar attitudes and behaviors. Sumarwan (2004) defines social class as another form of grouping society into different classes or groups. This grouping is generally based on material possessions of property. The social class is conceptualized as a psychological construct through the frame of view of life-view (Liu, 2011). In this case, the social class is one type of lens used by the individual to see the world around him, as well as the lens is a filter that filters out how information, experiences, and relationships are perceived by the individual. Individuals perceive themselves as part of the economic hierarchy and that they are in-group and out-group groups (Liu, 2011). The term Outgroup refers to individuals who are not in the same group (different from social class), and because the individual is an individual outside the group, the individual may be the target of mockery and marginalization (eg, classism). Being a member of a particular social class group signifies that the individual is also aware of the hierarchy and its status within the hierarchy (Liu, 2011). Classism is a behavior done to others, an experience of selfdiscrimination, and an internalized dissonance that arises when the individual perceives himself to be inconsistent with others (Liu, 2011). Classism is classified into four, namely:

1. Upward Classsism: It is a classic experienced by members of the upper social class group, one of which is the upper social class is considered as a bad individual, not attention.

2. Downward Classism: Is a form of classism experienced by lower social classes, such as the assumption that individuals in the lower social groups are lazy, ignorant and so forth.

3. Lateral Classism: It is a form of classism that occurs within the same social class, in the form of a horizontal comparison (Diwan, in Liu 2011), in which the individual evaluates himself and evaluated by others based on what others have and do in the same social class.

4. Internalized Classism: It is a feeling of anxiety, depression, anger, and frustration that arise because of the inability to maintain its position on a particular social class.

\section{RESEARCH METHODS}

The research method used in this research is Research and Development research method. Research and Develop is chosen because this method is in accordance with the research objectives to be achieved, namely to produce a product in the form of development of career counseling counseling program. Furthermore, Borg and Gall (1989) argue that in research and development, the stages are a cycle that includes a review of the findings of field research related to the product developed. Borg and Gall (2003) adapted the Dick, Carey and Carey system approach model of 10 steps to implement R \& D strategies that include: 1. Measuring needs to identify objectives (Assess needs to identify goals), 2. Conducting an instructional analysis, 3. Analyze learners and contexts, 4. Formulate learning objectives (Write performance objectives), 5. Develop assessment instruments (Develop assessment instruments), 6. Develop learning strategies (Develop instructional strategy), 7. Develop and specify learning materials (Develop and select instructional material), 8. Design and conduct formative evaluation of instruction, 9. Revision of instructional program (Revise instruction), 10. Design and conduct sumatif evaluation (Design and conduct summative evaluation).

Data collection techniques conducted in conducting study needs are 1) interviews and questionnaires Instruments used are: 1) the instrument of work adaptation, career making decision self-efficacy and classroom instrument While the interview guide using SCWM (social class world view model). 


\section{RESULTS}

Based on the results of tests conducted by experts in guidance and counseling of the program, then obtained data as follows:

Table 1.1. Expert Test Results

\begin{tabular}{|c|c|c|c|}
\hline No & Aspects & Rating & Description \\
\hline \multirow[t]{3}{*}{1} & \multicolumn{3}{|c|}{ Standard of Competencies } \\
\hline & Standards of & & \\
\hline & $\begin{array}{l}\text { Competencies } \\
\text { of students }\end{array}$ & 3 & Good \\
\hline \multirow[t]{8}{*}{2} & \multicolumn{3}{|c|}{$\begin{array}{l}\text { Organizational Framework: structure, } \\
\text { time elements, and activities }\end{array}$} \\
\hline & \multicolumn{3}{|c|}{ Structure of } \\
\hline & \multicolumn{3}{|l|}{ Components } \\
\hline & Assumption, & 3 & Good \\
\hline & \multicolumn{3}{|l|}{ Program) } \\
\hline & \\
\hline & Time & 3 & Good \\
\hline & $\begin{array}{l}\text { Component } \\
\text { Program }\end{array}$ & 3 & Good \\
\hline \multirow[t]{4}{*}{3} & \multicolumn{3}{|c|}{ Resources } \\
\hline & Personnel & 3 & Good \\
\hline & Financially & 3 & Good \\
\hline & Politics & 3 & Good \\
\hline \multirow[t]{4}{*}{4} & \multicolumn{3}{|c|}{$\begin{array}{c}\text { Development, Management, and } \\
\text { accountability }\end{array}$} \\
\hline & Asesment & 3 & Good \\
\hline & Evaluation & 3 & Good \\
\hline & Sum & 30 & Good \\
\hline
\end{tabular}

Based on the results of the expert test, overall assessment of the program is categorized well. It's just that researchers need to adjust the timing of classical guidance services activities with the form of activities given to students, so that all service objectives can be achieved through these activities. In addition, in service objectives the researcher needs to pay attention back to the use of appropriate instructional verbs according to the existing standards. In addition to being assessed by counselors and counselors, the program is also tested by one of the users who is the guidance and counseling teacher at the school, Dra Elsje M. Tatontos, who teaches at State Vocational High School 1, follows the results of the user test:
Table 1.2 User Test Results

\begin{tabular}{|c|c|c|c|}
\hline No & Aspects & Rating & Description \\
\hline \multirow[t]{3}{*}{1} & \multicolumn{3}{|c|}{ Standard of Competency } \\
\hline & Competency & & \\
\hline & $\begin{array}{c}\text { Standards of } \\
\text { student }\end{array}$ & 4 & Very Good \\
\hline \multirow[t]{8}{*}{2} & \multicolumn{3}{|c|}{$\begin{array}{c}\text { Organizational Framework: structure, } \\
\text { time, and activities }\end{array}$} \\
\hline & \multicolumn{3}{|c|}{ Components } \\
\hline & of structure & \multirow{3}{*}{4} & \multirow{3}{*}{ Very Good } \\
\hline & (Definition, & & \\
\hline & $\begin{array}{l}\text { Rational } \\
\text { Program) }\end{array}$ & & \\
\hline & Vision and & 4 & Very Good \\
\hline & Time & 4 & Very Good \\
\hline & $\begin{array}{l}\text { Component } \\
\text { of Program }\end{array}$ & 4 & Very Good \\
\hline \multirow[t]{4}{*}{3} & \multicolumn{3}{|c|}{ Resources } \\
\hline & Personnel & 3 & Good \\
\hline & Financially & 3 & Good \\
\hline & Politics & 4 & Very Good \\
\hline \multirow[t]{4}{*}{4} & \multicolumn{3}{|c|}{$\begin{array}{l}\text { Development, Management, and } \\
\text { Accountability }\end{array}$} \\
\hline & Assessment & 3 & Good \\
\hline & Evaluation & 3 & Good \\
\hline & Sum & 36 & Very Good \\
\hline
\end{tabular}

Based on the results of the user test, it is found that the program is very well used in the state vocational high schools of information and communication technology city of Tangerang. However, according to BK teachers in the personnel and financial section is quite difficult to be done in school. In terms of providing funding for BK teachers to attend seminars / training / training related to multicultural which cost more than Rp. 500.000 , the school will only provide funds not more than Rp.200.000 and even then only for one BK teacher every year. Typically, BK teachers in public schools rely solely on training run by government agencies or government-funded agencies, so there is no need to request funding from schools. As for assessment and evaluation, BK teachers find it difficult to conduct assessment and evaluation activities in accordance with this program and still need to re-learn for good assessment and evaluation.

\section{CONCLUSIONS}

After passing the various stages in this study, it can be concluded that: Referring to the results of hypothetical tests conducted by experts in the field of guidance and counseling, the planning is made in the program-based career counseling and social counseling is said to be good to be implemented in vocational schools The country of information and communication technology of Tangerang city. This can be seen from all aspects of the assessment that get a good assessment. Because in the design of the program has included the competence of students in accordance with the objectives of the program; Structure of components that conform to program 
objectives consisting of definitions, assumptions and rational programs; There is an analysis of the results of the assessment of the students 'needs and the students' environmental assessment as the foundation for creating the program, there is a vision of the mission as well as the time element in accordance with the objectives of the programming, as well as the guidance and counseling services component in accordance with the program development objectives.

\section{IMPLICATIONS}

This social class-based career-based counseling and counseling program is needed by the city's vocational high school students of information and communication technology of Tangerang city. This program is needed to assist students in improving their willingness to work, ie the capacity they feel in making work decisions even if they have obstacles. In this program there is not only material that will improve students' skill and softskill, but also help students realize and overcome the obstacles they face especially with regard to their social class.

\section{RECOMMENDATION}

The suggestions that researchers can give related to this research are as follows:

1. Based on the background of the problems and findings of preliminary study data and needs analysis, this social class-based career-based counseling and counseling program is only intended for students in the public vocational schools of information and communication technology. It is therefore desirable for other researchers to re-introduce a social class-based guidance and counseling program in other areas of BK services or on the same issue but in different areas.

2. This study should be continued by conducting a limited trial, and continuing on a broad trial to ensure its effectiveness is demonstrable.

Based on the findings of field data and research results, suggestions can be given to the counseling sciences education faculty study program in order to cooperate with MGBK or ABKIN to conduct training on multicultural counseling to BK teachers.

\section{REFERENCES}

[1] Badrujaman. A 2011. Theory and Application of Guidance and Counseling Program Evaluation. Jakarta. PT. Index.

[2] Bandura, A. (1986). Self-efficacy. In A. Bandura (Ed.), Social foundation of thought and action: A social cognitive theory (pp.390-453). Englewood Cliffs, NJ: Prentice Hall.
[3] Official news statistics no.85 / $11 /$ th. XVII, November 5, 2014 downloaded from www.bps.go.id on September 2, 2015

[4] Blustein, D. L., (2006). The psychology of working: A new perspective for career development, counseling, and public policy. Mahwah, NJ: Lawrence Erlbaum Associates.

[5] Blustein, D. L, Kenna, A.C., Gill, N., DeVoy, Julia E. (2008). The Psychology of Working: A new framework for counseling practice and public policy. The Career Development Quarterly. Vol 56. 294-308.

[6] Blustein, D. L., McWhirter, E. H., \& Perry J.C. (2005). An emancipatory communitarian approach to vocational development, theory, research, and practice. The Counseling Psychologist. 33 (2) 141-179.

[7] Booth, C. S. (2005). The Relationship between Career Aspiration, Multiple Role Planning Attitudes, and Wellness in African-American and Caucasian Undergraduate Women. The University of North Carolina. Http://libres.uncg.edu/ir/ecu/listing.aspx?id=880 downloaded on September 3, 2015

[8] Borg W.R., Gall, J.P., Gall, M.D. (1983). Educational Research, an Introduction. New York and London. Longman Inc.

[9] Bradley, R. H., \& Corwyn, R. F. (2002). Socioeconomic status and child development. Annual Review of Psychology. 53, 371-399.

[10] Brown, M. T., Fukanaga, C., Umemoto, D., \& Wicker, L. (1996). Annual Review, 1990-1996: Social class, work, and retirement behavior. Journal of Vocational Behavior, 49, 159-189.

[11] Brown, S.D., \& Lent, R. W. (Eds.). (2005). Career Development and Counseling: Putting Theory and Research to Work. Hoboken, NJ: John Wiley \& Sons.

[12] Brown, S. D., \& Ryan Krane, N. (2000). Four (or five) sessions and a cloud of dust: Old assumptions and new observations about career counseling. In S. D. Brown \& R. W. Lent (Eds.). Handbook of counseling psychology (3rd ed., Pp. 740-766). New York: Wiley.

[13]Deci, E. L., \& Ryan, R. M. (1985). Intrinsic Motivation And Self Determination In Human Development. New York: Plenum.

[14]Dick, W., Carey, L., and Carey, J.O., (2015). The Systematic Design of Instruction eight edition. USA: Pearson.

[15] Diemer, M. A., Ali, S. R. (2009). Integrating social class into vocational psychology: Theory and practice implications. Journal of Career Assessment. 17, 247-265.

[16] Duncan, G. J., \& Brooks-Gunn, J. (Eds.). (1997). Consequences Of Growing Up Poor. New York, NY: Russell Sage Foundation

[17] Duffy, R. D. \& Dick, B. J. (2009). Beyond the self: External influences in the career 
development process. The Career Development Quarterly. 58, 29-43.

[18] Elizabeth, B. Hurlock. (2002). Developmental Psychology: An Approach Throughout The Life Span (vol. 5). Jakarta: Erlangga.

[19] Evans, G. W. (2004). The environment of childhood poverty. American Psychologist, 59, 77-92.

[20]Freeman, S. C. 1993. Donald Super: A Perspective on Career Development. Journal of Career Development, Vol. 19 (4). Human Sciences Press, Inc. 255 - 264: University of North Carolina at Greensboro.

[21] Gay, L.R. (1991). Educational Evaluation and Measurement; Com-petencies for Analysis, s and Application Second edition. New York: Macmillan Publishing Company.

[22] Gibson, R. L. and Mitchell, M.H. (1995). Intoduction to Counseling and Guidance. Englewood Cliffs - New Jersey: Prentice-Hall Inc.

[23] Gisbers, N. C \& Henderson, P. (2006). Developing and Managing Your School Guidance and Counseling Program. United State: American Counseling Assosiation.

[24] Herr, E. L., Cramer, S. H., \& Niles, S. G. (2004). Career Guidance and Counseling Through The Lifespan: Systematic Approaches (6th ed.). Needham Heights, MA: Allyn \& Bacon.

[25] Kawakib, Jawahirul. (2008). Relationship Between Intelligence, Career self-efficay, Status of Parents Social Economy and Decision Making Career High School Students in Pamekasan District. Thesis. Guidance and Counseling Study Program, Graduate Program of State University of Malang.

[26] Keller, F. J., \& Viteles, M. S. (1937). Vocational Guidance Throughout The World. New York: W. W. Norton \& Co., Inc.

[27] Kotler, P. \& Amstrong, G. (2008). Principles of Marketing. 12th eds. USA: Pearson Practice Hall

[28] Lapan, R.T., Gysbers, N. C., \& Sun, Y. (1997). The impact of more fully implemented guidance programs on the school experience of high school students: A statewide evaluation study. Journal of Counseling \& Development. 75, 292302.

[29]Liu, W.M., Fridman., \& Hall, T.E.T. (2008). Social class in school counseling. In H.L.K. Coleman \& C. Yeh (eds), Handbook Of School Counseling (pp. 145-157)

[30] Liu, W. M. (2011). Social Class and Classism in the Helping Professions: Research, Theory, and Practice. LA: Sage

[31] Mansur, Djailan. (2005). Relationship Between Social Economic Status of Parents, Self Concept, and Student Career Decision Making MAN. Thesis. Study Program Guidance and Counseling, Graduate Program State University of Malang,
[32] McLoyd, V.C. (1998). Socioeconomic disadvantages and child development. American Psichologist. 53, 185-204.

[33] Mulyono, Ari Dwi N.I. (2014). Influence of Technology Development, Socio-Economic Status, Career Information, and Learning Process on Career Aspiration of Vocational School Students in Kebumen District. Thesis. Yogyakarta: Pascasarja Program, Yogyakarta State University.

[34] Munandir, (1996), Career Guidance Program at School, Jakarta: PPTA - Ditjen Dikti Depdikbud. Soegiyoharto, Rinny (2007),

[35] Nurihsan, Ahmad Juntika. (2005). Strategy of Guidance and Counseling Services. Bandung: Refika Aditama

[36] O'Brien, Karen M., et. Al. (1999). Broadening career horizon for students in at-risk environment. The Career Development Quarterly, 47, 215-229

[37] Osipow, S. H. (1983). Theories of Career Development. Englewood Cliffs - New Jersey: Prentice-Hall Inc.

[38] Perry, N. \& Van Zandt, Z. (2006). Focus on the future: A Career Development Curriculum for secondary school. USA: Idebate Press Book

[39] Sharf, Richard S. (1992). Applying Career Developmental Theory to Counseling. California: Brooks.

[40] Slameto. (2003). Learning and Its Affecting Factors. Jakarta: Rineka Cipta.

[41]Slavin, Robert E. (2012). Educational Psychology: Theory and Practice, 10th edition. USA: Allyn \& Bacon

[42] Solberg, V. S., Close, W., \& Metz, A. J. (2002). Promoting success pathways for middle and high school students: Introducing the adaptive success identity plan for shool counselor. In C. L Juntunen \& D. R. Atkinson's (Eds.) Counseling across the lifespan: prevention and treatment (pp. 135-157). Thousand Oaks, CA: Sage Publication

[43] Sue, D. W., \& Sue, D. (2003). Counseling the culturally diverse: Theory and practice (4th ed.). New York: John Wiley \& Sons.

[44] Sunardi. (2008). The Essence of Career. Online at http://file.upi.edu [accessed on July 20, 2016

[45] Supriatna, M \& Nandang Budiman. (2012). Career Guidance in SMK. Online at http://file.upi.edu [accessed on May 7, 2016]

[46] Thompson E. W. \& Hickey V. Joseph. (2008). Society in Focus: An Intoduction to Sociology. 7th edition. USA: Pearson.

[47] Tischler, H. L. (2011). Introduction to Sociology. CA: Cencage

[48] Van den Akker. (1999). Principles and Methods of Development Research. London. In. Van den Akker, J., Branch, R.M., Gustafson, K., Nieveen, N., \& Plomp, T. (eds.) ". Design approaches and 
tools in educational and training. Dordrecht: Kluwer Academic Publisher.

[49] Warikoo, N. \& Carter, Prudence. Cultural explanation for racial and ethnic stratification in academic achievement: A call for a new and improved theory. Review of Educational Research. Vol 79. N0.1, 366-394.

[50] Walsh, W. B., \& Savickas, M. L. (Eds.). (2005).

Handbook of vocational psychology (3rd ed.). Mahwah, NJ: Lawrence Erlbaum Associates. 